UDC 631.354.2:633.85

\title{
TECHNICAL AND ECONOMIC EVALUATION OF EFFICIENCY OF HYDROSEEDER
}

\author{
L. V. Aniskevich, S. M. Deyneka
}

National University of Life and Environmental Sciences of Ukraine. Ukraine

Speciality of article: 133 - industry engineering.

Corresponding authors: deyneka5555@ukr.net.

Article history: Received - October 2019, Accepted - January 2020.

Bibl. 14, fig 2, tabl. 1.

Abstract. The article deals with a calculation of economic efficiency of the use of a prototype of a hydroseeder "Inna" which is aggregated with a motorblock and allows to sow small sprouted seeds of vegetable crops with simultaneous watering with small doses of a liquid.

Also, had done a comparison of the basic economic indicators of the experimental model of the hydroseeder and the seeder "Vinnitsya", which is introduction in a serial production for a seeding dry seeds.

The calculated economic effect of using a hydroseeder will be obtained by reducing the direct operating costs achieved by reducing labor costs and renovating.

The increase in productivity of the hydraulic fertilizer is increased due to the possibility of its aggregation with the motorblock and the installation of the recommended parameters of the nodes of the hydroseeding apparatus.

Key words: hydroseeder, efficiency, costs, cost, effect.

\section{Introduction}

Traditionally dry sown crop seed drills at a given depth and a given width of the aisle. Modern drills have a high reliability, better performance and provide quality planting different seeds in accordance with the agrotechnical requirements.

The disadvantage of such planters is the failure of the amicable shoots, especially seeds with a long germination.

Hydroseeder "Inna" is intended for small farms. It was created in order to save money to buy an expensive pelleted seed allows you to get even sprouts an ordinary vegetable seeds.

Also took the germinated seed will allow you to get an earlier harvest, when there is mass implementation of seasonal vegetables, so their price will be higher.

\section{Formulation of problem}

Another economic advantage of this planter is cultivation on the same plot a few vegetable crops in the spring and summer period by reducing the time from sowing to technical maturity.

Therefore, the economic effect from the use of hydroseeder obvious.

\section{Analysis of recent research results}

Issues of economic efficiency of use of domestic seeding equipment dedicated to the works [1-24], but their studies have not dealt with the use of small seeding machines.

\section{Purpose of research}

The purpose of this paper is to conduct a comparative economic evaluation of the use of the seeder for sowing dry seed "Vinnitsa" and hydroseeder "Inna".

\section{Results of research}

Development of small tools is one of the priority areas in agricultural engineering.

Of the existing means of mechanization of the most widely tillers, mini tractors with a set of tillers. Tools for sowing and planting crops and caring for them is not widespread, therefore there is a need for their development and implementation.

One of the possible solutions to the problem of ensuring household plots with means of small mechanization is the development and production of relatively simple and, as a consequence, cheap small tools, which would be completed with the working bodies and mechanisms of existing agricultural machinery.

However, it is necessary to consider manufacture of small tools in a home workshop from available materials.

Small seeder "Vinnitsa" designed for sowing smallseeded variety, namely vegetable crops. It has already been implemented in series production and has wide 
application. Serial drill "Vinnitsa" for example, for the base variant. Garoul "Inna" (Fig. 1) for sowing germinated seeds will present as new variant [2].

Hydroseeder "Inna" is particularly effective when applied seeding hydrated and germinated seeds on farmlands, suburban areas, in greenhouses for growing vegetable crops and medicinal plants, and is multifunctional. It can be used for irrigation of the culture directly in the line of a small dose of water or feed solution. Developed hydroseeder also allows for presowing preparation of seeds is a process of aeration (barbaraanne) seeds (Fig.2). It has a positive effect on the rate of seed germination and increasing germination. Its essence lies in the fact that seeds incubated in water at 20 $25^{\circ} \mathrm{C}$, which is aerated constantly (blown) oxygen installed on garoul compressor. This operation lasts for several hours.

After carrying out comparative experimental studies on the quality of sowing carrot base and upgraded the seeder obtained the following values of the quality indicators: coefficient of variation of depth of seeding the basic unit amounted to $7.8 \%$ and gdream of $5.6 \%$, the uniformity of distribution of seeds along the length of the row for base unit - by $53.9 \%$, for the upgraded - 71,9\%, field germination of seeds when planting the base unit is $68,4 \%$, a modernized version of $89.4 \%$. It is established that at application of hydroseeder substantially increase the uniformity of distribution of seeds along the length of the row. Simultaneously, it will increase seed germination, and coefficient of variation of depth of placement of seed in the furrow is reduced.

Economic efficiency from the introduction of the production was carried out according to the standard technique [1] on the basis of these plants and the results of field studies.

The performance of the unit shift time is determined by the formula:

$$
W_{z}=0,1 \cdot V_{d} \cdot B_{r} \cdot K_{t e},
$$

where: $V_{d}$ - actual average speed of movement of the unit, $\mathrm{km} / \mathrm{h}$,

$B_{r}-$ working width, m,

$K_{t e}-$ the coefficient characterizing the deviation of the technical performance of the unit from operating.

Transport of seeds in the seed bed is carried out with simultaneous introduction of water regulation effects $0,0821 / \mathrm{m}$.

Labor costs per unit of work are determined by the expression:

$$
T_{r}=n / W_{\mathrm{z}}
$$

where: $n$ - the number of workers employed on the operations people.

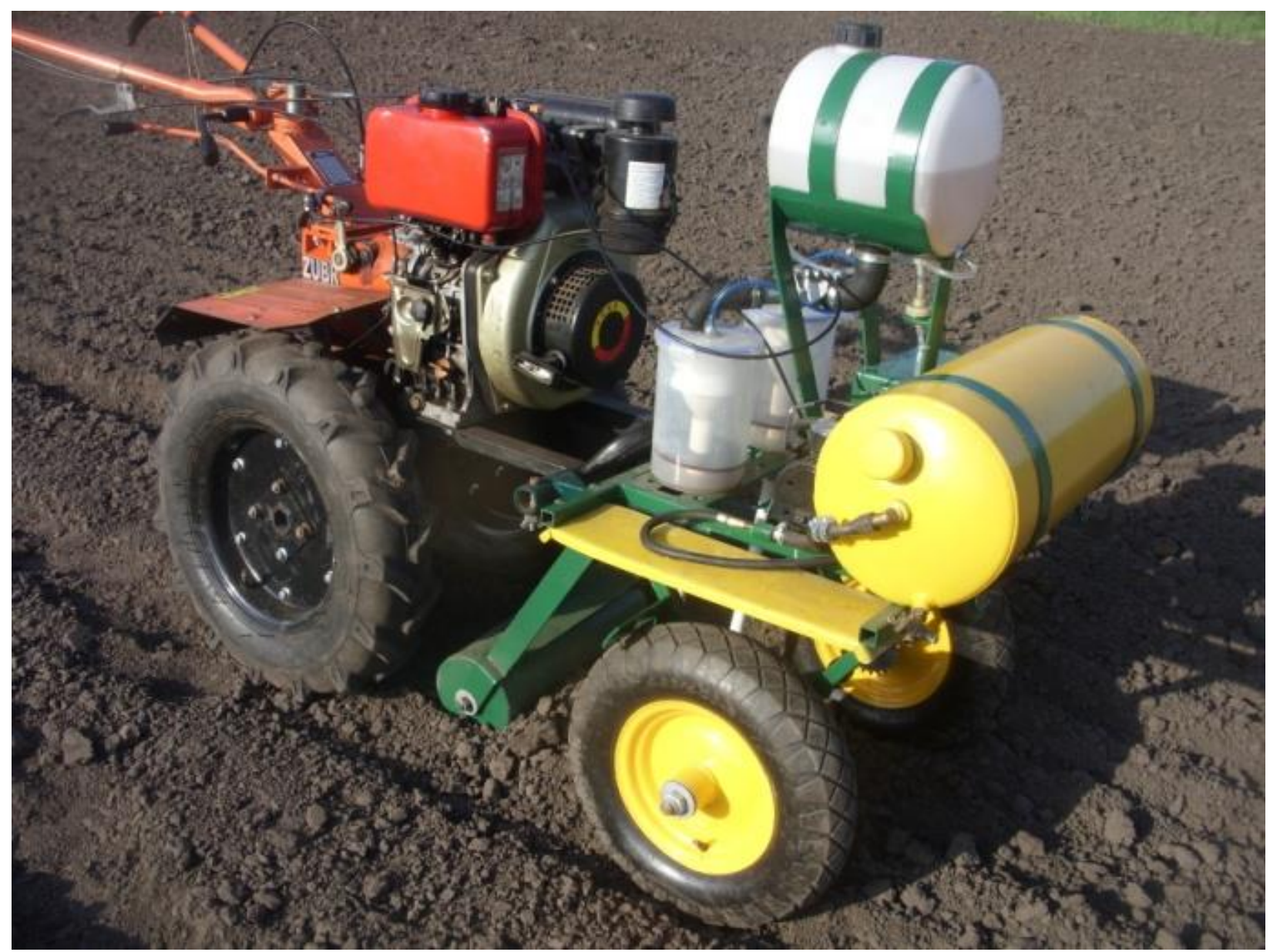

Fig. 1. Hydroseeder "Inna". 


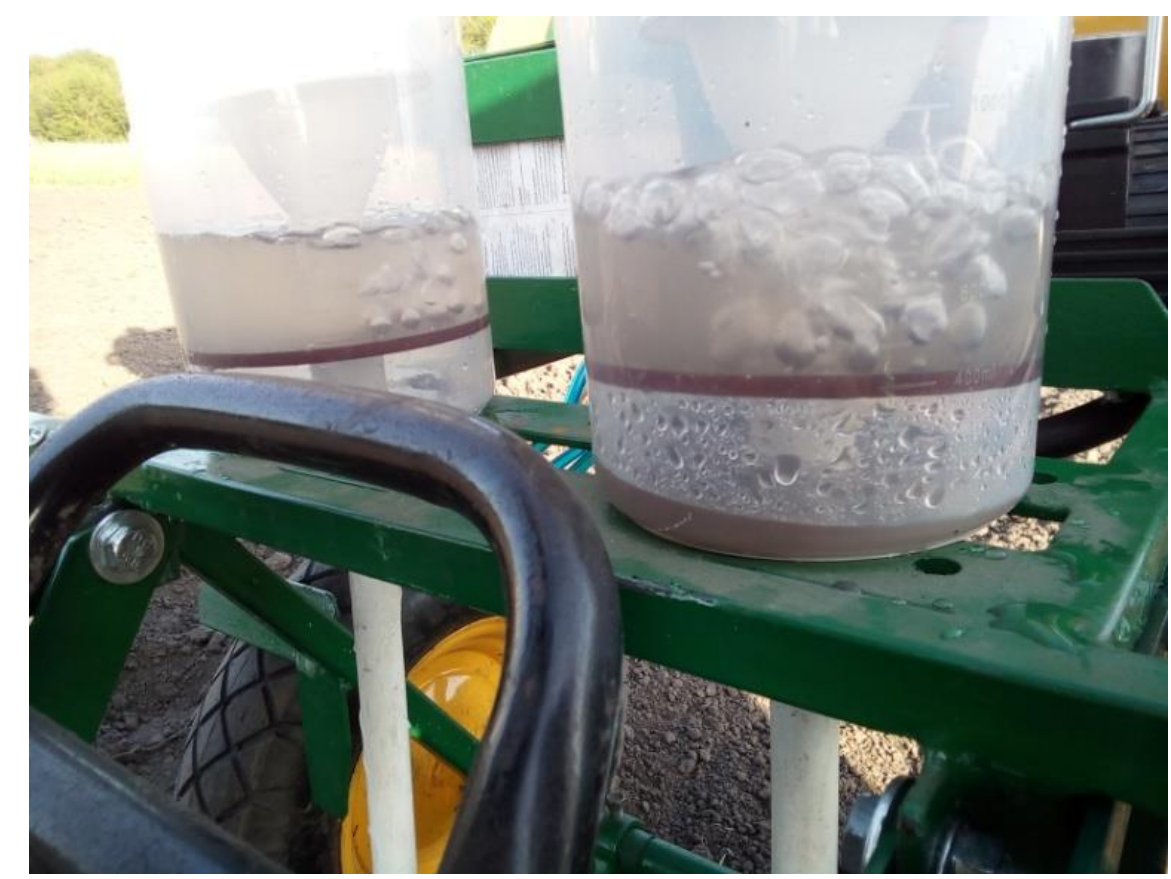

Fig. 2. Process barbaraanne seeds.

The specific energy is expressed by the equality:

$$
F=N_{e n} / W_{\mathrm{z}},
$$

where: $N_{e n}$ - operating engine power, $\mathrm{kW}$.

For tillers $N_{e n}=4,41 \mathrm{~kW}$.

The specific energy consumption shows the power consumption of the engine per unit volume of soil and is given by:

$$
E=O V / a U,
$$

where: $\mathrm{O}$ - traction resistance, $\mathrm{kN}$

$$
\begin{aligned}
& \mathrm{V} \text { - speed, } \mathrm{m} / \mathrm{s} \text {, } \\
& \mathrm{a} \text { - working depth, } \mathrm{m} \text {, } \\
& \mathrm{U} \text { - width, } \mathrm{m} \text {. }
\end{aligned}
$$

Reduction in specific energy consumption is:

$$
D=\left(E_{b}-E_{n} / E_{b}\right) 100 \% \text {, }
$$
$\mathrm{UAH} /$ ha

Direct operating costs per unit volume of works:

$$
C=Z+\mathrm{A}+Q+\mathrm{R}
$$

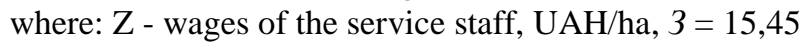

$\mathrm{Q}$ - fuel and lubricants, UAH/ha

A - depreciation, UAH/ha (Am - tillers, As seeders),

$\mathrm{R}$ - repair and maintenance services, $\mathrm{UAH} / \mathrm{ha}$.

$$
Z=Z_{d} / W_{z}
$$

Hourly pay rates for staff (UAH/hour):

- when sowing $Z_{S}=16,12$.

Deductions depreciation and amortization (UAH/ha) is calculated by the formula:

$$
A=B_{i} a / W_{z} \text {, }
$$

where: $B$ - book value: motoblock $=24125 \mathrm{UAH}$ planter

"Vinnitsa" = 655 UAH, "Inna" = 5600 UAH.

a - coefficient contributions for the renovation: tillers and $=0,1$, seeders $\mathrm{a}=0,142$.

$t$ - seasonal load: for tillers $t=1600$, seeder $t=200, h$

Deductions for repairs and maintenance, UAH/ha:

$$
R=B_{i} r / W_{z} \mathrm{t}
$$

where: $r$ - ratio deductions for repairs and maintenance. For tillers $r=0,13$, seeder $r=0,07$.

The cost of fuel and lubricants is determined by the formula:

$$
Q=g_{n} P_{m}
$$

where: $P_{n}-$ given the unit cost of fuel and lubricants, UAH. $\mathrm{Pm}=32 \mathrm{UAH} / \mathrm{kg}$.

Specific capital investment is determined by the formula:

$$
K_{n}=B_{i} / W_{z} t,
$$

Given the specific costs are calculated according to the formula, $\mathrm{UAH} / \mathrm{ha}$ :

$$
i=B+K_{n} K_{m}
$$

where: $K_{m}-$ normative coefficient of efficiency, $\mathrm{Km}=0,15$.

The annual economic effect from the exploitation of the new planter, $\mathrm{UAH} /$ year:

$$
E=\left(C_{\mathrm{b}}-C_{\mathrm{n}}\right) T
$$

where: $C_{\mathrm{b}}, C_{\mathrm{n}}$ - given the costs in the baseline and the new planter, $\mathrm{UAH} / \mathrm{ha}$,

$T$ - the annual volume of work, ha.

$$
T=t W
$$

$E=(186,88-172,3) 200=2920 \mathrm{UAH}$

Using the table we can conclude that the application of the proposed model hydroseeder reduces the cost of labor per unit of work, energy and power consumption for the operation of sowing, which gives grounds to assert that this technology is energy efficient. Of course there are some additional maintenance costs of the planters and tillers, but they cancel due to high prices for early vegetables.

So field studies were conducted in the spring of 2018. To test the operation hydroseeder conducted a study of the process of sowing germinated seeds of carrots. This year the prices for carrot are, especially in the early production broke all records ( $1 \mathrm{EUR} / \mathrm{kg}$ ). Of course then the prices are somewhat decreased, but even during the mass harvest remain fairly high $(0,5 \mathrm{EUR} / \mathrm{kg})$. Studies have shown that the use of hydroseeder for sowing germinated seeds of vegetable crops gives you the ability to crop of carrots in mid-June. 
Table 1. Indicators of comparative economic efficiency when planting carrots.

\begin{tabular}{|c|c|c|}
\hline The characteristics & Base variant & New variant \\
\hline The number of sown rows, PCs & 1 & 2 \\
\hline Seeding rate $\mathrm{kg} / \mathrm{ha}$ & 3,5 & 4 \\
\hline Productivity per hour, ha/h operating time & 0,09 & 0,533 \\
\hline Speed, $\mathrm{km} / \mathrm{h}$ & 2,8 & 5 \\
\hline Fuel consumption, $1 /$ ha & - & 0,47 \\
\hline Weight, $\mathrm{kg}$ & 5.6 & 53 \\
\hline Depth, cm & $1-5$ & $1-5$ \\
\hline Labor costs per unit of work person/ $h$ & 0,27 & 0,25 \\
\hline he specific energy & 32,89 & 30,42 \\
\hline The specific energy consumption, $\mathrm{kJ} / \mathrm{m}$ & 68,57 & 56,6 \\
\hline Wage of workers, UAH/ha & 4,39 & 4,06 \\
\hline $\begin{array}{l}\text { Contributions for the renovation: walking tractor } \\
\text { seeders }\end{array}$ & 10,67 & $\begin{array}{c}7,2 \\
9,96 \\
\end{array}$ \\
\hline $\begin{array}{l}\text { The annual volume of work, ha: } \\
\text { walking tractor } \\
\text { seeders }\end{array}$ & $\begin{array}{c}- \\
0,738\end{array}$ & $\begin{array}{l}4,5 \\
1,79\end{array}$ \\
\hline $\begin{array}{l}\text { Deductions for repairs and maintenance, } \\
\text { UAH/ha:walking tractor } \\
\text { seeders }\end{array}$ & 5,26 & $\begin{array}{l}9,36 \\
4,91\end{array}$ \\
\hline Fuel and lubricants, UAH/ha & - & 136,5 \\
\hline $\begin{array}{l}\text { Direct operating costs per unit volume of works: } \\
\text { UAH/ha } \\
\text { walking tractor } \\
\text { seeders }\end{array}$ & $\begin{array}{c}- \\
15,93\end{array}$ & $\begin{array}{c}157,12 \\
14,87\end{array}$ \\
\hline $\begin{array}{l}\text { Specific capital investments, UAH } \\
\text { walking tractor } \\
\text { seeders } \\
\text { total }\end{array}$ & $\begin{array}{l}75,2 \\
75,2\end{array}$ & $\begin{array}{l}72,05 \\
70,17 \\
142,22\end{array}$ \\
\hline $\begin{array}{l}\text { Given specific costs: } \\
\text { walking tractor } \\
\text { seeders } \\
\text { total }\end{array}$ & $\begin{array}{l}27,21 \\
27,21\end{array}$ & $\begin{array}{c}167,9 \\
25,4 \\
193,3\end{array}$ \\
\hline
\end{tabular}

\section{Conclusions}

Conclusions and outlook: improving the economic efficiency of production of vegetables associated with productivity increase - the main indicator that characterizes the production and business activities of the enterprise.

1. One of the most important means of determining production efficiency is profitability. This figure covers the expenses for production and sales, net income, productivity and production costs.

2. The annual economic effect from the use of hydroseeder will be 2920 UAH. The economic effect will be obtained from the reduction of direct operating costs, achieved by reducing labor costs and renovation. Productivity hydroseeder increases due to the possibility of aggregation with a walk-behind tractor and a set of recommended parameters of nodes garbisch apparatus.

3. However, there are factors which reduce productivity hydroseeder. This is a limited capacity vodonosnyh mixture (up to 6.3 liters).

4. When using prototype hydroseeder observed improvement compared to the base model: decrease of specific energy costs by $17 \%$, reduced labor costs by $20.2 \%$.
5. In determining economic efficiency hydroseeder for objective reasons, were not taken into account: reducing the technological reliability of the prototype hydroseeder, increased crop yields due to the parallel watering small doses of liquid.

6. The main advantage of the introduction hydroseeder "Inna" is the ability of germinated sowing small seeds of vegetable crops without injury to the shoots with simultaneous mtropolitan. This gives you the opportunity to get early crops of vegetables at minimum cost. Enter the market before competitors allows to receive additional profit due to the difference in the market value of products up to $35 \%$.

7. In our opinion, the economic indicators are objective and can't change much, especially not affect the potential effectiveness of using gtoal. However, it is possible to further improve the design ggrowing apparatus, which can positively affect the economic efficiency of hydroseeder.

\section{References}

1. DSTU 4397: (2005). Methods of economic evaluation of equipment at the stage of the test. Kyiv. Derzhspozhyvstandart of Ukraine. 16. 
2. Kushnarev S. A., Deineka S. M., Mahmudov I. I., Ivanov E. S. (2016). Hydroseeder for sowing small seed vegetable crops. Patent of Ukraine model № 111666 Patent of Ukraine for Utility Model No. 111666. Byul. Bulletin. no. 22.

3. Rathke, G.-W., Behrens, T., Diepenbrock W. (2006). Integrated nitrogen management strategies to improve seed yielg, oil content and nitrogen efficiency of winter oilseed rapeseed (Brassica napus L.). Agriculture Ecosystems \& Environment. Nr.117. 80-108.

4. Statistical yearbook of Lithania. (2013). 671.

5. Špokas, L. Velička, R., Rimkevičiene, $\quad$ M., Marcinkevičienè $R$. (2005). Ripening dinamics and natural falling of spring rapeseed seeds. Agricultural Sciences. Nr. 3. 29-38. (in Lithania).

6. Špokas, L., Velička, A., Marcinkevičienè, R., Domeika R. (2004). Optimierung des Erntezeitpunktes von Sommerraps durch die Sortenwahl. Die Bodenkultur. Bd. 55, H.3. 113-120. (in Germany).

7. Morgan, C. L., Bruce, D. M., Child, R., Ladbrooke, Z. L., Arthur, A. E. (1998). Genetic variation for pod shatter resistance among lines of oilseed rapeseed developed from synthetic B. napus. Field crops Research Nr. 58. 153-165.

8. Šidlauskas, G., Bernotas, S. (2003). Some factors affecting seed yield of spring oilseed rapeseed (Brassica napus L.). Agronomy Research. Nr. 1(2). 229-243.

9. Pahkala, K., Sankari, H. (2001). Shatter loss as a result of pod shatter in spring rapeseed and spring turnip rapeseed in Finland. Agrikultural and food scince in Finland. Vol. 10. 209-216.

10. Price, J., S., Hobson, R. N., Neale, M. A., Bruce, D. M. (1996). Shatter losses in Commercial Harvesting of Oilseed Rape. Journal of Agricultural Engineering Research. (65), 3. 183-191.

11. Rademacher, T. (2003). Methodology for measuring of quality and loss-throughput behavior for combine harvesters under field conditions. VDI-MEG Kolloquium Landtechnik. Mähdrescher. 40, 83-94. (in Germany).

12. Rathke, G.-W., Behrens, T., Diepenbrock, W. (2006). Integrated nitrogen management strategies to improve seed yielg, oil content and nitrogen efficiency of winter oilseed rapeseed (Brassica napus L.) Agriculture Ecosystems \& Environment (117), 80-108.

13. Reckleben, A. Y., Vosshenrich, H. H. (2008). Getreideernte durch den Hochschnitt [Grain harvest by the high cut]. Getreide. (13) 2: 108-109. (in Germany).

14. Statistical yearbook of Lithania, (2013), 671.

15. Šidlauskas, G. and Bernotas, S. (2003). Some factors affecting seed yield of spring oilseed rapeseed (Brassica napus L.). Agronomy Research, 1 (2), 229-243.

16. Špokas, L., Velička, R., Rimkevičiene, M., Marcinkevičiené, R. (2005). Ripening dinamics and natural falling of spring rapeseed seeds. Vilnius. Agricultural Sciences. Nr. 3, 29-38. (in Lithania).

\section{Список літератури}

1. ДСТУ 4397: Методи економічної оцінки обладнання на етапі випробування. Київ. Держспоживстандарт України. 2005. 16.
2. Кушнарьов С. А., Дейнека С. М., Махмудов I. I., Іванов $E . \quad C$. Гідросівалка для посіву дрібних насіннєвих овочевих культур. Патент України модель № 111666 - Патент України на корисну модель № 111666. Бюл. Бюлетень. № 22. 2016.

3. Rathke, G.-W., Behrens, T., Diepenbrock W. Integrated nitrogen management strategies to improve seed yielg, oil content and nitrogen efficiency of winter oilseed rapeseed (Brassica napus L.). Agriculture Ecosystems \& Environment. Nr.117. 2006. P. 80-108.

4. Statistical yearbook of Lithania. 2013. 671 p.

5. Špokas, L. Velička, R., Rimkevičiene, M., Marcinkevičiene $R$. Ripening dinamics and natural falling of spring rapeseed seeds. Agricultural Sciences. Nr. 3. 2005. P. 29-38.

6. Špokas, L., Velička, A., Marcinkevičienè, R., Domeika $R$. Optimierung des Erntezeitpunktes von Sommerraps durch die Sortenwahl. Die Bodenkultur. Bd. 55, H.3. 2004. P. 113-120.

7. Morgan, C. L., Bruce, D. M., Child, R., Ladbrooke, Z. L., Arthur, A. E. Genetic variation for pod shatter resistance among lines of oilseed rapeseed developed from synthetic B. napus. Field crops Research Nr. 58. 1998. P. 153-165.

8. Šidlauskas, G., Bernotas, S. Some factors affecting seed yield of spring oilseed rapeseed (Brassica napus L.). Agronomy Research. 2003. Nr. 1(2). P. 229243.

9. Pahkala, K., Sankari, H. Shatter loss as a result of pod shatter in spring rapeseed and spring turnip rapeseed in Finland. Agrikultural and food scince in Finland. 2001. Vol. 10. P. 209-216.

10. Price, J., S., Hobson, R. N., Neale, M. A., Bruce, D. M. Shatter losses in Commercial Harvesting of Oilseed Rape. Journal of Agricultural Engineering Research. 1996. (65), 3. P. 183-191.

11. Rademacher, T. Methodology for measuring of quality and loss-throughput behavior for combine harvesters under field conditions. VDI-MEG Kolloquium Landtechnik. Mähdrescher. 2003. 40, P. 83-94.

12. Rathke, G.-W., Behrens, T., Diepenbrock, W. Integrated nitrogen management strategies to improve seed yielg, oil content and nitrogen efficiency of winter oilseed rapeseed (Brassica napus L.) Agriculture Ecosystems \& Environment. 2006. 117. P. 80-108.

13. Reckleben, A. Y., Vosshenrich, H. $H$. Getreideernte durch den Hochschnitt [Grain harvest by the high cut]. Getreide. 2008. (13) 2. P. 108-109.

14. Statistical yearbook of Lithania, 2013, 671 p.

15. Sidlauskas, G. and Bernotas, S. Some factors affecting seed yield of spring oilseed rapeseed (Brassica napus L.). Agronomy Research, 2003. 1 (2), P. 229-243.

16. Špokas, L., Velička, R., Rimkevičienè, M., Marcinkevičiené, $R$. Ripening dinamics and natural falling of spring rapeseed seeds. Vilnius. Agricultural Sciences. 2005. Nr. 3. P. 29-38.

\section{ТЕХНІКО-ЕКОНОМІЧНА ОЦІНКА ЕФЕКТИВНОСТІ ВИКОРИСТАННЯ ГІДРОСІВАЛКИ \\ Л. В. Аніскевич, С. М. Дайнека}


Анотація. У статті проведений розрахунок економічної ефективності використання дослідного зразка гідросівалки «Інна», що агрегатується 3 мотоблоком i дає можливість висівати пророщені насіння овочевих культур 3 одночасним поливом невеликими дозами рідини. Також проведено порівняння основних показників дослідного зразка гідросівалки і впроваджено в серійне виробництво сівалки для висіву сухого насіння «Вінниця». Розрахований економічний ефект від використання гідросівалки було взято від зниження прямих експлуатаційних витрат, досягнутих за рахунок зменшення витрат на працю і реновацію. Підвищення продуктивності праці збільшується за рахунок можливості іii агрегатування 3 мотоблоком i установкою рекомендованих параметрів вузлів гідровисівного апарату

Ключові слова: гідросівалка, ефективність, витрати, вартість, ефект.

\section{ТЕХНИКО-ЕКОНОМИЧЕСКАЯ ОЦЕНКА ЭФФЕКТИВНОСТИ ИСПОЛЬЗОВАНИЯ ГИДРОСЕЯЛКИ}

\section{Л. В. Анискевич, С. Н. Дайнека}

Аннотация. В статье произведен расчёт экономической эффективности использования опытного образца гидросеялки «Инна», что агрегатируется с мотоблоком и даёт возможность высевать пророщенные семена овощных культур с одновременным поливом небольшими дозами жидкости. Также произведено сравнение основных показателей опытного образца гидросеялки и внедренную в серийное производство сеялки для высева сухих семян «Винница». Рассчитанный экономический эффект от использования гидросеялки будет взят от снижения прямых эксплуатационных расходов, достигнутых за счет уменьшения расходов на труд и реновацию. Повышение продуктивности труда увеличивается за счет возможности её агрегатирования с мотоблоком и установкой рекомендуемых параметров узлов гидровысевающего аппарата

Ключевые слова: гидросеялка, эффективность, расходы, стоимость, эффект.

L. V. Aniskevich ORCID 0000-0002-4429-2020.

S. M. Deyneka ORCID 0000-0003-1015-2457. 